\title{
OS VESTÍGIOS PRÉ-HISTÓRICOS E A MATERIALIDADE SALAZARISTA. CONTRIBUTOS PARA UMA HISTÓRIA DA PRÉ-HISTÓRIA EM PORTUGAL
}

\author{
SÉRGIO ALEXANDRE GOMES ${ }^{(1)}$
}

Resumo:

\begin{abstract}
O salazarismo, enquanto regime totalitarista, tinha como objetivo a fabricação de um território e de uma população condizente com seus projetos. A ação articulada da propaganda e dos aparelhos de inculcação ideológica dessa fabricação operacionalizavam a construção de um horizonte de sentido pautado pela ideologia do regime. Neste artigo, iremos discutir o modo como os vestígios materiais pré-históricos foram integrados nesse horizonte de sentido e articulados com os restantes elementos que definem a materialidade salazarista. Para tal iremos centrar a nossa análise na obra de Mendes Corrêa, procurando demonstrar o modo como o seu programa de pesquisa atualiza o horizonte de sentido salazarista e, por conseguinte, a sua materialidade.
\end{abstract}

Palavras-chave: Estado-Novo, Práticas discursivas, Pré-histórica, Materialidade.

\begin{abstract}
:
Prehistoric materials and Salazar's materiality. Towards a History of Prehistory in Portugal

As a totalitarian regime, salazarism's objective was the creation of a territory and a population befitting of its projects. The articulation of propaganda and the apparatus of ideological indoctrination used in this creation constructed as horizon of meaning that was organised according to the regime's ideology. In this article, I will discuss how prehistoric material remains were integrated into this horizon of meaning and how they were articulated with the other elements that defined "Salazar's materiality". I will focus my analysis on the work of Mendes Corrêa, and try to demonstrate how his research reproduced "Salazar's horizon of meaning" and, therefore, its materiality.

Keywords: New State (Portugal); Discourse practices; Prehistory; Materiality.
\end{abstract}

\section{INTRODUÇÃO}

$\mathrm{O}$ estudo da arqueologia durante o Estado Novo é um tópico desenvolvido no âmbito das diferentes pesquisas que têm contribuído para o conhecimento da história da arqueologia em Portugal. Os diferentes inquéritos desenvolvidos contribuem para enquadrar o tópico enquanto um momento da história da disciplina em Portugal (e.g. FABIÃo 1999, 2011; Jorge E Jorge 1996; PIMENTA 1999), possibilitam também a sua conversão enquanto um caso específico para a compreensão da relação entre a arqueologia e a ideologia nacionalista (e.g. FABIÃO 1996) e, simultaneamente, num caso que permite a sua comparação com regimes políticos semelhantes (e.g. DÍAZANDREU 1997; GOMES 2006/07; MARTINS 2010). No fundo, tais estudos integram-se nas diferentes linhas de estudo que se definem no campo da história da arqueologia, com os quais se tenta dar conta da multiplicidade dos processos de disciplinarização, institucionalização e profissionalização da prática arqueológica ${ }^{1}$. Com um inquérito mais dirigido ao conhecimento da prática arqueológica no seu contexto histórico, existem estudos dirigidos à caracterização das dinâmicas institucionais (e.g. COELHO no prelo; MATOS 2012; MARTINS 2005,
2012/13; RAPOSO 1999, 2007/08, 2010), aos agentes que animam tais dinâmicas (e.g. CARDOSO 2001/02, 2008, 2010; MARTINS 2011b, 2011c, 2013), aos objetos de estudo partilhados pela comunidade de arqueólogos (e.g. CARDOSO 2002, 2010/11b; GOMES 2011b; MARTINS 2005, 2009; PIMENTA 2007) e ao modo como os vestígios arqueológicos eram integrados nas dinâmicas identitárias e sociais promovidas pelo regime (e.g. BRANDÃO 2008/09; GOMES ibidem; LILIOS 1995; MARTINS 2012).

O presente artigo tem como objetivo discutir o lugar dos vestígios materiais pré-históricos no "mundo salazarista", ou seja, pretende-se analisar a relação destes elementos com o horizonte de sentido construído pela propaganda e aparelhos de inculcação ideológica do Estado Novo durante as décadas de 1930 e 1940 (RosAs 2001). Neste sentido, a analítica que será desenvolvida tem como ponto de partida o cruzamento das metodologias da prática historiográfica (CERTEAU 1982 [1975]; MURRAY \& EVANS 2008) e da análise do discurso (FOUCAULT 1997 [1971]; MARTINS 1990). O objeto de estudo em análise é constituído por um conjunto de textos da obra de Mendes Corrêa sobre a pré-história portuguesa. Mendes Corrêa é uma

${ }^{(1)}$ Centro de Estudos em Arqueologia, Artes e Ciências do Património

${ }^{1}$ A propósito da multiplicidade de temas que concorrem neste campo de estudo, podemos referir, a título de exemplo, o estudo da importância do internacionalismo na história da arqueologia (e.g. DíAZ-ANDREU 2007; EVANS 1995; KAESER 2002) e o modo como tal relação se desenvolveu em Portugal durante o Estado Novo (e.g. GOMES 2011a; MARTINS 2011a, 2015; CARDOSO 2010/11a). 
figura incontornável na história da ciência em Portugal. A sua obra parte de uma perspectiva muito abrangente da antropologia, tendo como objetivo abarcar tudo o que "estivesse ligado ao homem, tanto no que concerne ao passado, como ao presente" (MATOS 2012: 324), trabalhando, deste modo, um conjunto de temas que, hoje em dia, se encontram dispersos por disciplinas autónomas (a geologia, a arqueologia, a antropologia biológica, a antropologia cultural e a primatologia), no sentido de gerar perspetivas agregadoras (ibidem), sendo neste nó de temas e linhas de pesquisa que se desenvolve o seu interesse e estudo pela préhistória. Antes de apresentar a análise desses textos, num primeiro momento serão abordados as dinâmicas que possibilitam a emergência do horizonte de sentido salazarista (MARTINS ibid; ROSAS ibid) no sentido de compreender os modos pelos quais se constrói a materialidade salazarista. Posteriormente, a obra de Mendes Corrêa serve de ponto de partida para tentar definir um quadro de relações que caracterizam os modos de articulação entre os vestígios materiais pré-históricos e tal materialidade $^{2}$.

\section{A MATERIALIDADE SALAZARISTA}

"Salazar avança alguns passos e o seu perfil recorta-se, com nitidez, sobre o pano fundo da paisagem, onda de Portugal atrás da qual outras ondas se escondem... Momentaneamente, a vista larga do horizonte satisfaz a sua visão larga, esse olhar que se finge pequenino, tímido, na selva da cidade, cheia de ciladas, mas que denuncia e revela a sua amplitude em frente da natureza leal, da natureza que não mente! Recuamos para não interromper o seu idílio com a terra que ele tem diante dos seus olhos, sua mãe ainda viva, sua mãe eterna!

Salazar está, agora, sozinho! Julga que está sozinho, diante do horizonte profundo... Mas engana-se. Portugal rodeia-o, envolve-o, abraça-o: ao Norte, ao Sul, a Este, a Oeste" (FERRO 2007 [1938]: 145).

O retrato que António Ferro faz de Salazar no pedestal do Caramulo, no final da $6 .^{\text {a }}$ Entrevista, é um retrato de Portugal. Ou o retrato de um projeto para Portugal, em que a portugalidade do horizonte e da figura é revelada metaforicamente por um avassalador abraço. Uma vez enleados, Salazar revela o seu verdadeiro olhar e Portugal a sua verdadeira extensão (Fig. 1). Esse parece ser o sentido da paisagem retratada. O olhar e a descrição metafórica que António Ferro faz deste abraço revela de modo objetivo a amplitude do projeto político em curso nas décadas 1930 e 1940 e o modo como se encontrava ancorado num "aparelho de inculcação ideológica autoritária, estatista, mergulhado no quotidiano das pessoas (ao nível das famílias, da escola, do trabalho, dos lazeres)" (ROSAS 2001: 1031). Tratava-se, no fundo, de colocar em marcha um trabalho de ressignificação da expressividade artística, dos costumes, da geografia e da história da nação (e.g. ACCiAiOUli 1998; CUNHA 2001; Melo 2001; Neto 2001; Ó 1999; Pimentel 2007) e de implementação de uma tecnologia de patriotização, na qual os dispositivos de controle e normalização convertiam o território e a população num recurso para o projeto de estado-nação idealizado pelo regime (MARTINS 1998). Neste trabalho de ressignificação, que é um trabalho de materialização (ou seja, de alteração dos modos de representação e das relações sociais), assistimos à construção de um horizonte de sentido em que se refaz a experiência das coisas. Na próxima sub-seção, desenvolveremos este tópico, centrando a análise no conceito de materialidade. Posteriormente, apresentamos uma síntese acerca das dinâmicas da edificação do horizonte de sentido salazarista.

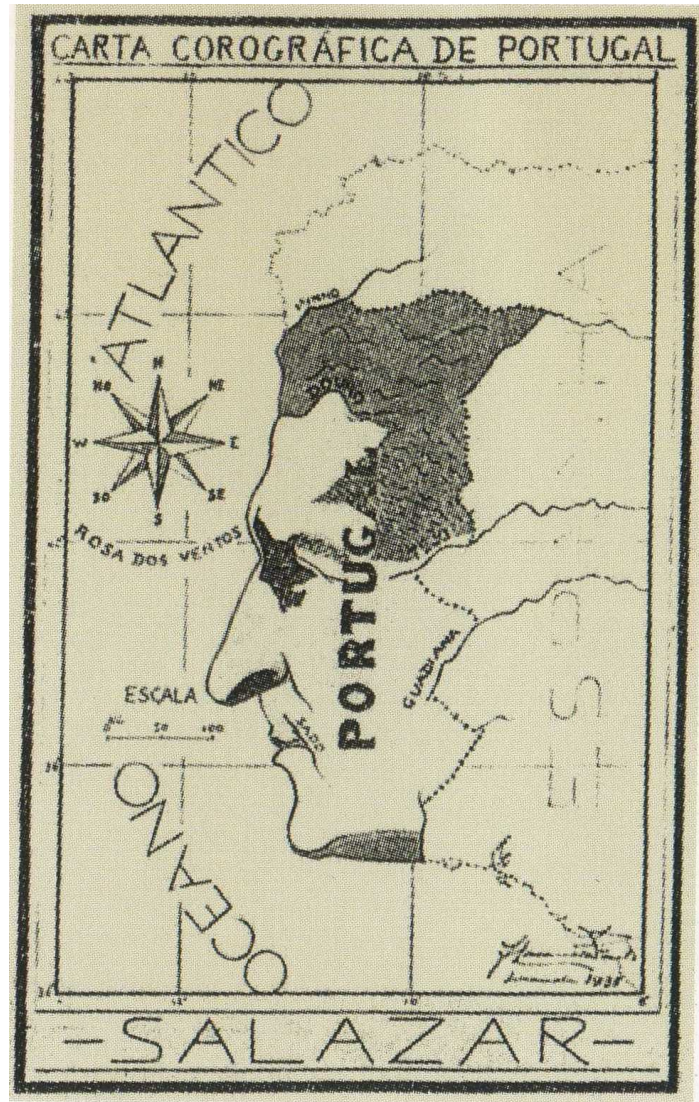

Fig. 1. Cartaz de propaganda política do Estado Novo (VIEIRA 2010: 87).

Fig. 1. Estado Novo's political propaganda flyer (VIEIRA 2010: 87).

\subsection{Materialidade: uma aproximação ao conceito}

A arqueologia, uma disciplina que estuda evidências materiais do passado, apresenta no âmago da sua prática uma interrogação acerca do senti- 
do dessas evidências, construindo diferentes estatutos epistemológicos para esses objetos de estudo, a partir dos quais desenvolve diferentes programas de conhecimento que, por sua vez, se multiplicam num sem número de imagens sobre o passado e a sua diferença. Na problemática que se forma em torno do sentido a construir para as evidências materiais do passado (e.g. HENARE et al 2007; INGOLD 2007; MiLler 2005; THOMAS 2004), o estudo da materialidade das evidências surge enquanto pesquisa centrada nos seus "modos de revelação" (THOMAS ibid: 214-218) ${ }^{3}$. Este programa de pesquisa ${ }^{4}$ pressupõe que habitamos o mundo num "horizonte de revelação" definido pela nossa condição de finitude que, por sua vez, se gera no diálogo entre as representações que fazemos do nosso passado e as expectativas que criamos para o nosso futuro num determinado contexto de experiência do mundo ${ }^{5}$. Neste diálogo geram-se os limites e as possibilidades da nossa ação e da nossa relação com o mundo da qual fazemos parte. Nesta ordem de ideias, o estudo da materialidade das evidências corresponde à edificação de um leque de configurações possíveis com que essas evidências passam a existir no mundo e, por conseguinte, passam a concorrer nas suas condições de experiência e transformação.

Considerando o programa de pesquisa definido no parágrafo anterior, interessa-nos, neste artigo, tentar compreender a dinâmica de construção da materialidade salazarista. Ou seja, trata-se de tentar compreender o modo como a ideologia do regime se entrosou no "horizonte de revelação", criando um mundo a que damos o nome de salazarista e $a i$, nesse mundo, compreender o lugar dos vestígios pré-históricos. Deste modo, o estudo da materialidade salazarista é um exercício de procura de práticas discursivas. Corresponde a uma tentativa de compreender o modo como se desenvolveu "uma tecnologia de normalização e de controlo da vida e dos corpos, isto é, um espaço de distribuição e de dispersão de valores, um sistema de normas, um campo de oposições estratégicas" (MARTINS 1998: 22). Neste sentido, investigar a materialidade salazarista é percorrer as práticas discursivas que governam a ocorrência das evidências materiais, exploram os circuitos que tais evidências possam vir a desenvolver e garantem a cristalização das suas capacidades de transformar o mundo em torno da figura do Homem Novo Estadonovista (RosAS 2001). No próximo sub-ponto, apresentaremos a génese desta figura, os seus contornos e as dinâmicas da sua fabricação.

\subsection{A mitologia, o horizonte de sentido, apare- lhos e engrenagens do projeto totalitarista do Homem Novo Estadonovista}

De acordo com F. Rosas (2001), o Estado Novo, nas décadas de 1930 e 1940, à semelhança do que acontecia noutros países fascistas ou fascizantes, é marcado por colocar em prática um projeto totalizante que visa o governo e controlo da população e do território (ibid: 1032). Assente numa ideia de "reeducação dos espíritos", este projeto caracterizou-se pelo propósito de "estabelecer uma ideia mítica de «essencialidade portuguesa», transtemporal e transclassista, que o Estado Novo reassumira" (ibid: 1034). Tal "essencialidade portuguesa" era sistematizada na seguinte série de mitos ideológicos fundadores:

O Mito Palingenético: que, perspetivando a história em ciclos de decadência e regeneração, institui o Estado Novo como um período de florescimento da Nação (a Renascença Portuguesa) (ibidem);

O Mito do Novo Nacionalismo: em associação com o mito anterior, assegura o caráter providencial do regime, isto é, o nacionalismo do Estado Novo apresenta-se como um momento de afirmação da "essencialidade portuguesa", traduzindo e certificando a sua concretização perante os novos desafios da nação (ibidem);

O Mito Imperial: decorrente da vocação imperial, civilizadora e cristã da nação promove uma ideia de uma nação "pluricontinental, plurirracial, una, indivisível e inalienável" (ibid: 1035);

O Mito da Ruralidade: trata-se de um mito de origem que, de certa forma, tenta resolver a tensão entre as dinâmicas de mudança que implicariam a modernização do país e valorização da tradição (ibidem);

O Mito da «Aurea Mediocritas»: ou o mito da pobreza honrada, estabelecendo um horizonte de sentido no qual a pobreza material

\footnotetext{
${ }^{3}$ De um modo muito resumido, podemos dizer que o autor propõe o estudo da materialidade enquanto alternativa a um programa de pesquisa que define o objeto de estudo em arqueologia enquanto "cultura material", num quadro de uma ontologia substancialista, que toma as evidências materiais enquanto resultado de diferentes processos de objetivação da ação humana (THOMAS ibid.: 202-222).

${ }^{4}$ Construído a partir de uma hermenêutica fenomenológica inspirada nas obras O Ser e o Tempo de M. Heidegger e Verdade e Método de H.G. Gadame

${ }^{4}$ Construí
${ }_{5}^{5}$ ibidem).

${ }^{5}$ Nas palavras do J. Thomas (2004: 217): "Disclosure is an event, or more accurately an unfolding process, in which the world gradually reveals itself to us (GUIGNON 2001: 36). It is finite because disclosure always takes place in relation to human beings, who are themselves finite beings. How we recognize and understand physical things is a consequence of the finitude of our past, present and future. Our past has happened, and has provided us with a restricted set of possibilities. In the present, we exist alongside other people and things, and yet none of the provides the foundation for an understanding of reality that tin possils our. awareness that those possibilities are ultimately limited by our mortality (POLT 2001: 69). All of this forms the context within which things become recognizable and salient to us. We occupy a horizon of disclosure, which we have no option but to find ourselves within. Living in a particular time and place a particular range of phenomena are revealed to us, but other things are unavoidably concealed, so that human existence is surrounded by a 'dark penumbra of unintelligibility' (YOUNG 2002: 9).”
} 
do país era ressignificada através de uma aura providencial, que naturalizava as condições de vida e do projeto nacional estadonovista (ibidem);

O Mito da Ordem Corporativa: que legitima a política corporativista com base numa perspetiva organicista da nação, fazendo dos portugueses um povo com vocação para o respeito e obediência à ordem, à hierarquia e à autoridade (ibid: 1034-1035);

O Mito da Essência Católica Portuguesa: a providencialidade dos outros mitos revela a vocação religiosa, cristã e católica de Portugal (ibid: 1035).

Esta mitologia definia, assim, a plataforma ontológica que viabilizava a apetência totalizante do projeto do governo (ibid: 1037). Os mitos acima descritos, desenvolvidos a partir dos múltiplos aspetos da ideologia do Estado Novo, varriam um leque diversificado de vivências, instaurando um "regime de revelação" que atualizava permanentemente a experiência do mundo. As Verdades Indiscutiveis, proclamadas por Salazar no décimo aniversário do 28 de maio, sintetizariam essa ontologia numa série de pressupostos éticos, cuja prática viabiliza a construção do Homem Estadonovista. Uma prática que o regime promoveu tanto na esfera pública como na esfera privada através de aparelhos de propaganda e inculcação ideológica (ibidem).

Nas dinâmicas de controlo e produção do Homem Novo estadonovista é possível reconhecer a existência de dois sistemas: o sistema de enunciação e o sistema de inculcação ideológica. O sistema de enunciação tinha como objetivo a depuração do conhecimento, a formulação de enunciados que concretizassem os ideais e os projetos do regime. $\mathrm{O}$ sistema de inculcação ideológica trataria da sua redistribuição, recriando contextualmente a matriz definida pelos enunciados (ibid: 1037- 1041). No âmbito do sistema de enunciação, F. Rosas (ibid) destaca o papel do Secretariado de Propaganda Nacional (SPN) e da Agência Geral das Colónias. O SPN fora criado em 1933, tratava-se de uma instituição em direta relação com a Presidência do Concelho e foi dirigido por António Ferro, constituindo-se como o elemento basilar da composição da imagem do regime e da construção da representação da Nação necessária aos projetos políticos, atuando também na formulação de estratégias de moldagem dos comportamentos necessários à sua prossecução. A Agência Geral das Colónias, ligada ao Ministério das Colónias, ocupava-se especificamente da consolidação da ideologia colonial tanto na Metrópole como no espaço colonial. No âmbito do sistema de inculcação ideológica, as dinâmicas eram asseguradas pelo Aparelho da Educação Nacional e pelo Aparelho Corporativo (ibid: 10421046). Em 1936, aquando da reforma nacionalista,
Carneiro Pacheco criou o Ministério da Educação Nacional onde estavam sediadas as três das mais importantes organizações de inculcação ideológica: a Mocidade Portuguesa (MP), a Obra das Mães pela Educação Nacional (OMEN) e, sob a tutela da OMEN, a Mocidade Portuguesa Feminina (MPF). Se o Aparelho da Educação Nacional se especificara na moldagem de papéis de género, o Aparelho Corporativo encarregou-se de identificar e controlar os grupos sociais em função das suas atividades profissionais e ocupações através da Junta Central das Casas do Povo (JCCP) e da Fundação Nacional para a Alegria no Trabalho (FNAT). A JCCP, criada em 1945, dirigia as Casas do Povo (uma das células base da política corporativista do Estado Novo) assegurando, assim, a vigilância do país inteiro e adaptando as estratégias em função dos contextos geográficos que compunham o território, no sentido de formar a territorialidade necessária ao projeto político. A FNAT, criada em 1935, tinha como objetivo a organização das ocupações dos trabalhadores, nomeadamente em meio urbano, no sentido de formar uma mão de obra coincidente com o modelo ideológico do "homemtrabalhador".

Do imenso e polimorfo aparelho políticoburocrático construído durante as décadas de 1930 e 1940 resultaria, assim, um programa de ação que visava a moldagem da vida nacional. Uma moldagem pautada, por exemplo, pela segmentarização e institucionalização das especificidades regionais formalizadas em termos de "tradições". As tradições, ao contrário dos costumes, correspondem a cristalizações de comportamentos que assumem uma dinâmica ritual das representações das comunidades (HoBsBAwn 1992[1983]). A sua rigidez formal decorre da necessidade de construir a perenidade da imagem da Nação promovida pelo regime. A sua institucionalização dissemina tanto os conteúdos dessas tradições como a burocracia estatal que subjaz à sua criação. É neste sentido que as Corporações, enquanto elementos da esfera da administração política, traduzem a ontologia mítica do Estado Novo para uma prática identitária. As Casas do Povo materializam esse cruzamento entre o mito e o governo constituindo-se como alicerce do ritual de celebração dessa ordem da essencialidade portuguesa construída pelo Estado Novo. Como salienta Daniel Melo (2001: 72): "Não é já só o campo que representa a expressão máxima de uma identidade nacional, é a própria institucionalização corporativa rural que funciona como criação ideal. As casas do povo são simbolicamente erigidas no modelo perfeito desta simbiose entre o regime e o povo, personificando, ao nível microcósmico, um relação umbilical que possibilita a vitalidade do corpo nacional". Neste entrosamento da ideologia com as realidades que pretende organizar/controlar institui-se, deste modo, uma prática discursiva em que a materialidade das evidências 
materiais é edificada no sentido de criar uma experiência de sentido na qual a experiência da expressividade identitária é uma estratégia tecnocrata e burocrática, que concretiza o projeto totalitarista de fabricação do Homem Novo Estadonovista.

\section{A MATERIALIDADE SALAZARISTA DOS VESTÍGIOS PRÉ-HISTÓRICOS NA PRÉ- HISTÓRIA DE MENDES CORRÊA}

\subsection{Introdução}

A prática arqueológica de Mendes Corrêa fazia parte de um inquérito holístico que pretendia explicar a humanidade enquanto entidade simultaneamente natural e histórica ${ }^{6}$. Tal prática científi$\mathrm{ca}^{7}$, em associação a uma atividade política em sintonia com o governo e ideologia salazarista, acabaria por adquirir uma tendência de pendor nacionalista, na qual emergem diferentes linhas de pesquisa que concretizam a ideologia nacionalista ${ }^{8}$. No conjunto das linhas de pesquisa desenvolvidas por Mendes Corrêa é de destacar o estudo da "etnogénese do povo português", no qual sobressaem os seus trabalhos enquanto pré-historiador'. Nesta sua pesquisa, não só desenvolveu trabalho de campo $^{10}$, como produziu três importantes sínteses acerca da pré-história em território nacional: a primeira corresponde ao livro Os Povos Primitivos da Lusitânia, publicado em 1924; a segunda, intitulada A Lusitânia pré-romana, corresponde a um capítulo do volume 1 da História de Portugal de Damião Peres (1928); por último, a terceira síntese é apresentada em Raças do Império (1943), na secção relativa à Metrópole. Apesar do interesse em focar a análise e a discussão nestas sínteses, neste artigo pretendemos procurar o quadro conceptual que lhes subjaz ${ }^{11}$. Na definição deste quadro, embora fosse importante fazer uma genealogia das influências de outros autores no pensamento de Mendes Corrêa ${ }^{12}$, centraremos a análise no sentido de compreender os esquemas de significação que permitem o interesse nos vestígios pré-históricos enquanto objeto de estudo no quadro da etnogénese da nação e da agenda nacionalista que subjaz à prática científica de Mendes Corrêa ${ }^{13}$. O processo de significação dos vestígios arqueológicos é apenas uma parte da constituição da materialidade préhistórica, cuja discussão implica a análise dos múltiplos processos de que a arqueologia dispõe para animar tal materialização (prospeção, escavação e musealização, por exemplo). Porém, neste artigo apenas incidimos na prática da escrita inerente a esses processos, procurando nos textos o articulado de ideias que faz emergir a materialidade salazarista nos vestígios pré-históricos.

\subsection{O passado enquanto objeto de pesquisa e de lição}

"Abisma-se a inteligência a perscrutar o mistério, confunde-se com a desproporção dos meios e dos resultados, extasia-se ante a permanência do milagre, $\mathrm{e}$ não se sabe que homem, rasgo ou sacrifício há-de pôr acima dos mais - a não ser exactamente o facto fundamental e primeiro de haver raça portuguesa estabelecida no seu lar independente e cristão nesta faixa atlântica da Península" (SALAZAR 1940: 256).

Na perscrutação da história impõe-se a clarividência do seu mistério: haver raça portuguesa. A ordem imperativa de Salazar acerca do assunto encontra no trabalho de Mendes Corrêa a forma de uma narrativa que historiciza o Homem Novo Estadonovista. Um dos aspetos fundamentais na construção dessa historização é a exploração das leis $d a$ hereditariedade. Estas leis asseguram uma visão de continuidade entre o presente e o passado. Uma visão na qual o estudo do passado se converte numa lição sobre a transtemporalidade do Homem Novo Estadonovista para os herdeiros do presente:

"O presente, nós, não somos senão um instante punctiforme numa longa cadeia, numa imensa unidade, no tempo indefinido, no ciclo tenaz da vida universal, da vida que irrompe vitoriosa das vastas necrópoles, das enormes hecatombes, chama brotando de cinzas, esfôrço contínuo, luta heróica, contra forças destruïdoras, pela permanência, pela eternidade" (CORRÊA 1940 [1938]: 183).

Instante, cadeia, unidade e ciclo são configurações em que a narrativa sobre o passado se cons-

\footnotetext{
${ }^{6}$ A problematização da obra de Mendes Corrêa (o seu percurso científico, profissional, institucional, político...) implica o desenvolvimento de múltiplas perspetivas (e.g. MARTINS 2011c) e a definição de uma linha de pesquisa específica no âmbito da história da ciência (e.g. MATOS 2012) que excedem o propósito deste artigo.

${ }^{7}$ Mendes Corrêa foi, em múltiplos aspetos, um arqueólogo que trabalhou no sentido de conferir à arqueologia o papel de disciplina científica independente em articulação com diferentes áreas disciplinares (para o desenvolvimento deste tópico, consultar e.g. CARDOSO 2010, 2011; MARTINS 2011d).

${ }^{8}$ Sobre a relação entre as agendas científicas e políticas de Mendes Corrêa, ver o trabalho de Patrícia Ferraz Matos (2012).

${ }^{9}$ Sobre a questão dos seus estudos sobre a etnogénese do povo português consultar Geo-historiografia da Cultura Castreja de J. Ramiro Pimenta (2007), para além dos textos referidos nas notas anteriores.

${ }^{10}$ No qual se destaca, por exemplo, as intervenções arqueológicas em concheiros (e.g. ABRUNHOSA 2012; CARDOSO 1999; 2010/11b; CARDOSO \& ROLÃO

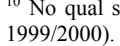

${ }^{11}$ Apesar da importância de abordar estas sínteses neste artigo, a sua análise implicaria uma escala de análise de pormenor que excede o propósito deste artigo. A este propósito, refira-se que num trabalho anterior, ensaiámos essa análise (GoMEs 2011b: 462-477). Neste momento, encontramo-nos a desenvolver tal estudo, problematizando o papel da mitologia do Homem Novo Estadonovista nas diferentes sínteses de Mendes Corrêa, nomeadamente em Raças do Império.

${ }^{12}$ Relativamente ao modo como Mendes Corrêa foi entrosando o seu seu pensamento com outros autores da antropologia e da arqueologia, consulte-se os trabalhos referidos nas notas $6,7,8 \mathrm{e} 9$.

${ }_{13}^{13}$ Nesta análise iremos privilegiar textos escritos durante as décadas de 1930 e 1940 . Porém, é de realçar que parte das ideias que constam nesses textos já se encontravam em elaboração em décadas anteriores (como é possível constatar num texto de 1919 que será apresentado). Deste modo, é de realçar que no entrosamento que vamos registar entre o pensamento de Mendes Corrêa e a ideologia do Estado Novo não podemos ver exclusivamente uma influência direta do contexto político na sua obra, mas uma confluência de ideias oriundas de práticas distintas.
} 
trói rumo à eternidade. São diagramas que impõem a condição de herdeiros à população portuguesa das décadas de 1930 e 1940, posicionando-as enquanto instante punctiforme no rumo à eternidade. Porém, "conjunto de herdeiros" e "rumo" não são elementos distintos. Na narrativa dos herdeiros, a biologia e a história não são narrações paralelas, mas uma história natural em que se marca

“(...) a coexistência e as ligações de dois aspectos essenciais da vida humana: as energias biológicas, orgânicas interiores, que têm a sua mais completa expressão na potencialidade maravilhosa e espontânea dos factores germinais, da hereditariedade, e as realizações da mente e da actividade dos homens, cuja expressão mais fiel é, a seu turno, a cultura, sob as suas variadas modalidades que não são apenas construções artificiais e transitórias mas também clarões magníficos dessa chama imaterial e eterna que é o próprio Espírito" (CORRÊA 1944: VI).

O Espírito do Homem Novo Estadonovista é, então, uma formação orgânica. Uma formação delimitável em instantes, cadeias, unidades $e$ ciclos... clarões magníficos a que se dá o nome de cultura. Existe, nesta imagem do mundo, uma aproximação entre o pensamento de Mendes Corrêa e a que nos é sugerida pelo nacionalismo cultural de Johann Gottfried von Herder e Johann Gottlieb Fichte, onde a Nação é um reduto imanente de singularidade (a que se regressa) e vontade (que se encarna como forma de vida) (BERLIN 1999). Aliás, é esta visão da Nação que viabiliza também a ordem e a política corporativista. Uma lei e uma ordem que fazem parte da mitologia usada pelo regime na implementação do projeto totalizante (ROSAS 2001: 1034-1035). Tal lei e ordem concorre na edificação da condição de herdeiro do Homem Novo Estadonovista. Uma condição que obriga a cuidar da herança, sendo o estudo do passado uma forma de a resgatar e conservar. Isto porque,

“(...) os métodos científicos permitem, dentro de certa medida, o cortar de clarões reveladores no negrume desses tempos primevos, descrevendo-nos, com alguma aproximação, estas terras e os seus habitantes em tão remotas épocas e deixando-nos escutar, para além do silêncio esfíngico de milénios decorridos, o clamor de multidões heróicas e sofredoras, adivinhar os anseios individuais e colectivos de almas como as nossas, e descobrir as raízes bio-telúricas das vontades que construiriam a Pátria" (CORRÊA 1943: 110).

O estudo do passado é, fundamentalmente, um processo de criar clarões sobre um tempo remoto do qual não há lembrança. Nesses clarões constituem-se as heranças que se pretende resgatar. Um resgate que as encadeia na narrativa do presente. A ciência projeta a luz no negrume e faz falar $o$ silêncio esfíngico de milénios. Dá a falar a imagem que ela própria constrói e, nesse discurso, sedentariza a história. Converte a história num conjunto de clareiras entrelaçado no território do presente. Neste movimento institui-se também uma memória da Nação. Uma memória que decorre de um conjunto de técnicas de lembrança que une o passado ao presente. Uma memória que não dá conta do silêncio. Ou que faz desse silêncio a moldura da verdade da narrativa que se conta. A memória fica, então, como reduto dessas lembranças. Um reduto em que se jogam as possibilidades de compreender o presente. E que, nesse jogo, naturaliza os modos pelos quais se invoca o passado enquanto técnica de resgate que cria lembranças. Uma lembrança que, como veremos, teria a forma de uma lição para o presente.

O passado e a memória criam-se então num jogo que faz das ciências históricas um conjunto de técnicas de resgates. Um conjunto de técnicas que produzem lembranças a partir das quais se tece a narrativa sobre o passado. Uma narrativa que tenta criar a sequência das configurações do Espírito até ao presente. Na criação desta sequência, que se forja pelas leis da hereditariedade, criam-se conceitos e modos de organizar as diferenças que, ordenando a narrativa, ordenam também o mundo a partir da qual é criada:

"A hereditariedade é o mais forte principio vital: o meio é um estatuário paciente que vae cinzelando lentamente o bloco - por vezes tão lentamente que as variações escapam à observação do homem.

Nem porisso o meio deixa de ser um elemento importantissimo em antropologia, como em toda a biologia.

A situação geográfica, a configuração do solo, a sua natureza geológica, a vizinhança do mar ou de cursos de agua, a temperatura, a humidade, a pressão atmosférica, os ventos, a luz, os pântanos, a vegetação, a fauna, o próprio carácter das paisagens, são factores naturaes de primacial interesse na vida dos povos. Alguns desses factores implicam já os que resultam das necessidades de alimentação, vestuário e habitação, do modo de vida, da organização social, e de reacção do homem sôbre o homem. Mas impossivel é levar até ás origens a destrinça dos complexos factores telúricos e sociaes, e a raça aparece-nos em certa altura consubstanciando todo esse determinismo e constituindo o termo aparente duma evolução.

Contra a opinião de [Gabriel] Tarde, as palavras génio dum povo ou duma raça não representam uma expressão literária sem sentido. Evidentemente a acção social e a consciência colectiva duma raça dissociam-se numa infinidade de factos distintos, cujo laço no entanto o psicólogo, o sociólogo e o historiador conseguem descobrir. É uma expressão tão legítima como, por exemplo, a expressão a religião dum povo. Cada indivíduo é crente e praticante a seu modo; nem porisso deixa de existir uma reli- 
gião comum, com traços característicos de devoção moral, fé, proseletismo, tolerância, ritual, etc. Simplesmente o génio dum povo é o facto mais alto, que abrange a consciência e a actividade social em todas as suas formas.

A alma dum pôvo - escreve Gustave Le Bon, não é uma concepção metafísica, mas uma realidade muito viva. É formada duma estratificação atávica, de tradições, de ideias, de modos de pensar, até de preconceitos. Da sua solidez depende a força duma nação" (CORRÊA 1919: 19-21).

A uma mundanidade bio-telúrica, feita de cruzamentos entre genes, meios e artifícios, Mendes Corrêa contrapõe uma imagem de raça que explica esses cruzamentos. Uma imagem que, não dando conta até às origens a destrinça dos complexos factores telúricos e sociaes, apresenta as condições para organizar as singularidades que se vêem nos cruzamentos e as condições da sua transformação. A raça parece, então, ser o conceito ordenador que pode explicar a diversidade do mundo. A sua força ordenadora tanto advém da capacidade de explicar a realidade como, na ausência de explicação, de segurar o mistério providencial de haver raça portuguesa. A raça é, assim, a moldura colocada a uma ideia de laço que expressa a infinidade de factos distintos em que se constituem as diferenças dos elementos que compõem o mundo. Pela raciologia, a complexidade dos cruzamentos em que se constitui a heterogeneidade do mundo é desdobrada em unidades. A ideia de raça permite que a estranheza da diversidade seja conduzida a uma grelha classificativa familiar onde as unidades se explicam na topografia da sua distribuição. Isto é, domestica-se a diferença pela sua sistematização em raças. A raça converte-se, pois, simultaneamente, na moldura que se coloca às diferenças e no laço que constrói a coesão dos diferentes elementos que participam na unidade que a moldura define. Esta sua plasticidade conceptual torna-se mais acentuada. A raça surge também como a possibilidade de representar um povo, ou de ser a alma desse povo, podendo também ser correlativa de uma Nação ou de influenciar a nacionalidade. Para além de tudo isto, a raça é também o nome que se pode dar à herança que as leis da hereditariedade permitem resgatar ao passado:

"A raça é um passado muitas vezes secular, o resíduo ancestral e, como tal, uma experiência palpável do caracter e do valor social dum povo" (CORRÊA 1919:29).

A arqueologia de Mendes Corrêa inscreve-se no objetivo de reconhecer o passado secular da raça. De, nos clarões sobre o negrume dos tempos remotos, encontrar os elementos que tornam possível a experiência de tornar material o caráter e o valor social dum povo. De procurar uma essência entre os acidentes da história, ou seja, de procurar as formações orgânicas que são o Espírito de um povo. Esta indiferenciação que caracteriza o uso do conceito de raça por parte de Mendes Corrêa é sintomática do pendor totalizante que o investigador lhe confere. Neste seu entendimento, a raça é apresentada como possibilidade de reconfiguração de uma série de dualidades: biológico e histórico; natural e político; material e espiritual; ação individual e ação coletiva; singular e universal; religioso e laico.... ${ }^{14}$ Perante estas cisões que animam os discursos sobre a existência das unidades políticas, o modo como o conceito de raça é apropriado por parte deste autor, vai no sentido de as reverter em linhas de complementaridade que forjam a unidade racial ${ }^{15}$. Os elementos das dualidades são entendidos como correlativos de forças que se complementam e cujo cruzamento (o laço) permite a formação das raças. Deste modo, a raça torna-se uma ficção edificante que, ordenando o mundo, se vai naturalizando enquanto modo de o entender. Isto é, vai sedentarizando a experiência nessa história natural que a raça permite contar. Essa sedentarização é mais eficaz porque é a narrativa das raízes do mundo, uma narrativa que enraíza o mundo e se enraíza como modo de o entender. Trata-se, pois, de um duplo movimento de sedentarização de uma ideia que, nessa duplicidade, se reforça e reifica continuamente. Porém, sendo uma história que se sedentariza, nem por isso se completa. Isto é, a sedentarização, enquanto movimento totalizante, domestica o desconhecido, integrando-o como parte do mundo que se constrói nesse movimento ${ }^{16}$. Nessa domesticação, o desconhecido é integrado como parte integrante da história das raízes do mundo, não como limite da história que se conta, mas como possibilidade de avanço dessa história. Trata-se, como já referimos, de uma estratégia de abordar $o$ silêncio esfingico de milénios, ou seja, de o discursificar enquanto parte integrante da história. Um silêncio que se dá a ver enquanto mistério, enquanto parte obscura de um enigma em desvendamento.

\footnotetext{
${ }^{14}$ Veja-se, por exemplo, essa reconfiguração na reação de Mendes Corrêa à tese de Damião Peres que fez do contexto político em que se movia Dom Afonso Henriques o "berço de Portugal": "Se um Estado como o nosso dependesse apenas da vontade humana desprovida de raízes na terra e no sangue deste povo, bem Henriques o "berço de Portugal": "Se um Estado como o nosso dependesse apenas da vontade humana desprovida de raizes na terra e no sangue deste povo, be
contingente seria o seu destino. Se a vontade individual sofre todos os riscos da liberdade, podendo enfraquecer ou orientar-se em sentidos vários, a vontade coletiva não é também perseverante, não se traduz em realizações definitivas, se a não anima uma energia de continuïdade secular. Essa energia só pode vir de Deus e das fôrças milenárias do germe e da terra" (CORRÊA 1943: 106). À ênfase que Damião Peres coloca no contexto político, Mendes Corrêa contrapõe a precariedade política da unidade que se forjou nesses conflitos, explicando que o seu sucesso deve ser entendido como a manifestação da concreção de uma série de fatores cuja interação, em última análise, radica na vontade de Deus, no germe e na terra. Ou seja, estamos face a uma perspetiva que emerge da sua visão/ ideologia organicista que atualiza o mito da ordem corporativista salazarista.

${ }^{15}$ Relativamente à ênfase que Mendes Corrêa foi dando aos pólos da dualidade em que se forja a ideia de raça é possível reconhecer diferentes modos de tecer a sua articulação e o peso de cada um na definição de unidades raciais. Simultaneamente, assiste-se também a diferentes posições no que diz respeito ao modo como a classificação racial poderia ser usada enquanto referência para a construção de hierarquias (MATOS 2012: 158-169).

${ }^{16}$ A sedentarização é o movimento pelo qual se constrói o horizonte de sentido que, quando abalado pelo que fica excluído do horizonte, trata de avançar e domesticar a zona de desconhecimento (ver nota 5).
} 
Sendo a perpetuação desse enigma, dessa história incompleta, que vai alimentando e dirigindo o movimento de sedentarização. Destes mistérios, Mendes Corrêa sabe que

"Os seres vivos têm uma embriologia. Uma Nação, ser vivo, tem uma ontogénese, indubitàvelmente longa, complexa e obscura, mas real e necessária. Não há nascimento sem germe e sem um condicionalismo apropriado ao desenvolvimento. $\mathrm{O}$ germe do povo português não surgiu apenas há oito séculos; é multimilenário, como multimilenário é o seio materno que o gerou e agasalhou, esta terra bendita e formosa de Portugal" (CORRÊA 1944 [1940]: 32).

Sabe-se, então, que a Nação tem uma ontogénese. Sabe-se que ai se formou um elemento perene. Conhecem-se alguns dos movimentos do processo. Mas a sua eficácia enquanto explicação das coisas, não vem apenas do que daí se sabe. Vem do mistério que aí se constitui e que faz do conhecimento uma revelação. Porém, a força da narrativa, alicerçando-se nesses conhecimentos, aumenta a sua intensidade enquanto narrativa do mistério, real e necessário. O clarividente mistério que anima a sedentarização da história e a naturalização do presente:

"Se perante as nações que se erguessem contra a nossa autonomia, não pudéssemos defendernos senão alegando os nossos pergaminhos históricos, os nossos serviços incontestáveis à humanidade e à civilização, se reconhecêssemos que somos um agregado nacional fortuito, de gente desprovida de genes específicos que a individualizem perante os outros povos e constituam a base biológica estável duma forte e perene vontade de independência, se aceitássemos sem protesto que a nossa morada no mundo tanto podia ser este canto abençoado da Europa como qualquer outro e que nada devemos de especial e permanente como nação a esta terra que não pudéssemos dever a outra, se o nosso modo de ser nacional fôsse obra exclusiva de meia dúzia de barões medievos e não o resultado dum concurso lato e mais ou memos sinérgico de fôrças telúricas e germinais sob a alta protecção divina - sofreríamos grave risco de desagregação e morte. Diminuíamos o nosso próprio valor, as nossas qualidades intrínsecas, a confiança na solidez dessas virtudes, e, admitindo, contra a evidência, que nada de estrutural e orgânico nos separa de outros povos, correríamos, nós próprios, na mais lamentável e inexplicável renúncia, a entregar-lhes o facho sagrado que só nós, Portugueses, temos o direito de brandir e velar, como uma grande família antiga em torno do altar das suas devoções domésticas" (CORRÊA 1944 [1938]: 106-107).

Nesta sedentarização da história, como já referimos, a pressão sobre o passado exerce-se no sentido de condicionar a memória enquanto exercício de movimentos de lembrança sobre o silêncio.
Um condicionamento que privilegia a memória como um movimento de ordenação cronológica. Nesta prática cria-se uma narrativa histórica, cuja narração não é mais do que um exercício disciplinar que adequa a memória aos projetos do presente.

A arqueologia, enquanto saber que faz da memória uma disciplina, torna-se uma técnica de produção de testemunhos materiais da memória. Testemunhos que, no seu silêncio esfíngico de milénios, são convertidos em documentos que falam:

“A Pré-história e a Arqueologia são da maior importância como fontes documentais para a Psicologia e a Filosofia. Todo o objecto arqueológico deve ser encarado como um documento psicológico. Para mim (como já um dia proclamei nesta sala) na História não há, como queria Oliveira Martins, apenas mortos. Ela não é um cemitério, mas uma ressurreição. Mais: a Préhistória e a Arqueologia revelam-nos admiravelmente o eterno no mortal, o permanente e contínuo no transitório e no descontínuo. As ossadas das gerações desaparecidas são percorridas por um fluido imaterial que delas faz emanar os princípios eternos que o tempo não mata, que os maiores cataclismos não subvertem. Quem cultiva essas ciências não se impressiona nem atemoriza com as vitórias retumbantes dos maiores exércitos e com os clamores das maiores multidões, na hora que se vive. Porquê? Porque, quando essas vitórias ou esses clamores parecem consagrar as maiores calamidades e injustiças, se sabe que não deixará de vir, na sucessão dos tempos, a hora do triunfo para a Justiça e para a Bondade. Essa é a consagração eterna daqueles que são pela Verdade e pelo Bem" (CORRÊA 1954 [1951]: 329).

Todo o objecto arqueológico é, assim, processado num contínuo esquema de significações que o fazem correlativo, num primeiro momento, de uma psicologia e de uma filosofia e, posteriormente, de um conjunto de valores eternos. Ou seja, a sua inserção no horizonte de sentido do Homem Novo Estadonovista confere-lhe uma materialidade, em que os atributos físicos e a localização das coisas viabiliza a sua classificação cronológica. É criada uma grelha em que os testemunhos materiais se dão a conhecer enquanto artefactos. Essa artefactualidade das coisas viabiliza uma tipificação morfológica que remete para uma psicologia e uma filosofia. Trata-se, então, de um segundo momento de indexação, desta vez, viabilizado num regime de artefactualidade que possibilita a leitura de destrezas e competências humanas nos atributos físicos das coisas. Nesta indexação, as coisas tornam-se indícios de delimitações que a psicologia e a filosofia constroem, ou seja, o indício permite, então, presentificar essas delimitações. Tal indexação viabiliza, por seu turno, o que podemos considerar uma primeira manifestação da ressurreição do passado, de que nos fala Mendes Corrêa. Porém, este processo 
só termina a partir do momento em que as delimitações da psicologia e da filosofia que se lêem nos artefactos são contrastadas com os valores do contexto em que se dá essa leitura, constatando a sua permanência. $A i$ completa-se o ciclo da ressurreição, ou melhor, são criadas as condições para que o passado fale e se dê a ver: a Pré-história e a Arqueologia revelam admiravelmente o eterno no mortal, o permanente e contínuo no transitório e no descontínuo. Ou seja, o passado torna-se uma força do presente, uma força em que a perenidade, que advoga o projeto do presente, se revela enquanto narrativa que contribui para a catarse do restante conjunto das forças que constituem o Estado-Nação. Essa catarse, nos moldes em que se forja, traz consigo o movimento de sedentarização que naturaliza o presente. Movimento que cria, nas possibilidades do presente, a disponibilidade para receber as vitórias retumbantes dos maiores exércitos e as maiores calamidades $e$ injustiças, garantido que, entre esses episódios, não deixará de vir, na sucessão dos tempos, a hora do triunfo para a Justiça e para a Bondade. Fazendo dessa sucessão dos ciclos, a regra da história. Sedentarizam-se, assim, as possibilidades de vida no passado, no presente e no futuro, moldando-se a experiência do mundo a uma narrativa de valores eternos, em nome dos quais, tudo se justifica.

A Pré-história e a Arqueologia revelam-nos admiravelmente o eterno no mortal. A materialidade salazarista dos vestígios pré-históricos é um campo de citações onde se encontra o fluido imaterial dos princípios eternos que o tempo não mata. Tal como a obra do regime - a sua paisagem - torna palpável os seus valores (Fig. 2), a pré-história torna palpável a eternidade desses valores. Os vestígios pré-históricos são documentos de uma história e de uma lição onde são apresentadas realidades palpáveis. Uma realidade palpável produzida num projeto de pesquisa equiparável às estratégias de composição da propaganda do regime. A materialidade dos vestígios pré-históricos torna palpável o triunfo para Justiça e para a Bondade no passado, tal como o pensamento de Salazar torna palpável as realizações de tal Justiça e Bondade. Ao Homem Novo Estadonovista é dada a oportunidade de viver essas realizações e de experimentar a eternidade dos valores que subjazem nos vestígios pré-históricos.

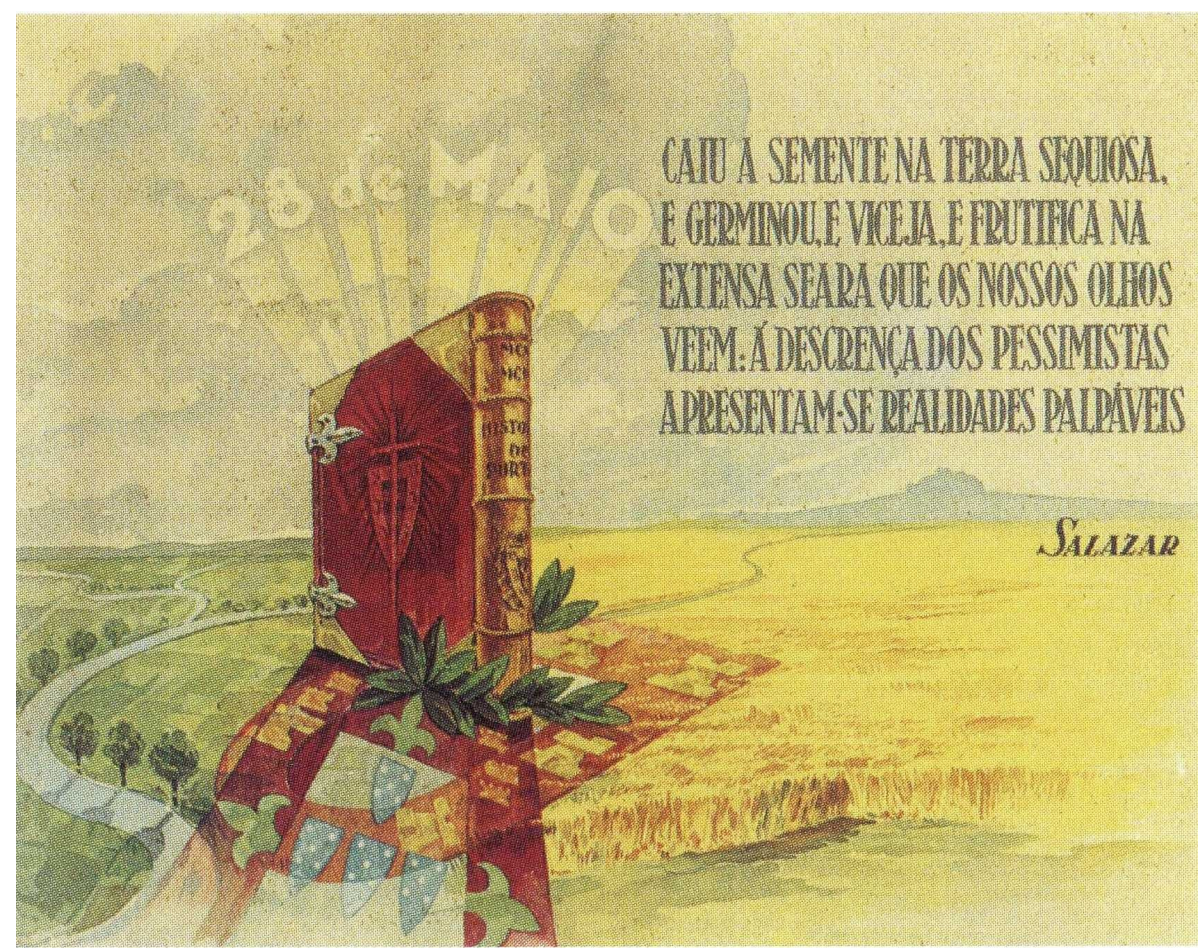

Fig. 2. Cartaz de propaganda política do Estado Novo (VIEIRA 2010: 95),

Fig. 2. Estado Novo's political propaganda flyer (VIEIRA 2010: 95).

Esta narrativa dos valores eternos faz-se pela construção de figuras evanescentes que, através do esquema de indexações em que se constrói o significado das coisas, é possível ver em todos os objectos arqueológicos. Ver num perpétuo movimento de recitação em que se constrói a portugalidade salaza- rista. Um recitação que, no caso da arqueologia, toma a forma de um enraizamento no qual a raça é uma forma de discursificar o passado. Um enraizamento de onde surgem figuras ressuscitadas que, pela recitação, atestam a verdade do governo. Quanto mais se vê esse passado, mais enraizado está o 
presente. Mais naturalizado o Homem e o projeto Estadonovista. E, assim, mais reduzido o mundo à experiência de um conjunto articulado de factos fundamentais e primeiros. As práticas que compõem a paisagem da portugalidade salazarista reificam em sucessivas ressignificações esses factos. Reificam a sua facticidade no sentido de fazer da paisagem um lugar de Verdade. O lugar das Grandes Certezas da Revolução Nacional. O lugar da incontestabilidade de Deus, da Pátria, da Autoridade, da Família e do Trabalho. Por conseguinte, lugar de solenidade onde a leitura do passado

"é ao mesmo tempo acto de devoção, acto de exaltação, acto de fé" (SALAZAR 1940: 258).

Actos que comemoram a paisagem num encadeado de significados que entrelaçam a biologia, a história e a fé. Actos que forjam as possibilidades para a sedentarização da história numa ideia de raça portuguesa que, por sua vez, é um enigmático entrelaçado de leis e vidas a desvendar. Um lugar de mistério de onde é possível dizer que

"não foi o povo que compreendeu o espírito da Revolução; foi a Revolução que soube interpretar o sentimento dto povo" (SALAZAR 1936: 138-139).

O lugar da política, tal como o lugar da préhistória e da arqueologia, legitima-se, então, como lugar de interpretação do povo. O lugar de uma teia em que as práticas se recitam face ao facto fundamental e primeiro de haver raça portuguesa. Facto fundamental e primeiro no qual se inscrevem os mitos do regime que vimos no ponto anterior. Um facto fundamental e primeiro que ordenaria o horizonte de sentido e, por conseguinte, a prática política e a prática arqueológica.

\section{CONSIDERAÇÕES FINAIS}

O Homem Novo Estadonovista é uma figura de um projeto totalitarista construída com base num conjunto de mitos que, explicando a natureza da população e do território de Portugal nos anos 1930 e 1940, definem um horizonte de sentido onde o programa de governo do regime é apresentado como um caminho de realização das verdades dessa mitologia (ROSAS 2001). A prática discursiva salazarista desenvolve uma tecnologia de patriotização que, direcionando aos corpos à experiência dessas verdades, fabrica os cidadãos necessários ao projeto do governo (MARTINS 1998). Neste contexto, podemos ver a produção do passado pela prática arqueológica enquanto um diálogo entre dois "modos de revelação" (THOMAS 2004): um deles corresponde ao processo de revelação proporcionado pelas teorias, métodos e modelos explicativos em que se constitui a praxis arqueológica; o outro diz respeito à revelação dos dados arqueológicos no horizonte de sentido salazarista. Neste segundo processo de revelação, os vestígios materiais arqueológicos são objeto de uma hermenêuti- ca que se desenvolve no sentido de ensaiar a verdade desses vestígios enquanto objetos produzidos por um saber autorizado, objetos reveladores de uma verdade sobre o passado da nação e, por conseguinte, objetos que são uma lição para o presente. Deste modo, neste segundo processo de revelação a materialidade dos vestígios materiais do passado é forjada para garantir que a experiência desses vestígios se constitui um lugar de reificação da ordem salazarista.

A análise da obra de Mendes Corrêa permitiunos ver como os vestígios materiais pré-históricos se produzem num programa de pesquisa operacionalizado pelas ideias de raça e hereditariedade articulado com os diferentes mitos do regime. Esta articulação é visível nos paralelismos que podemos tecer acerca da conceção do objeto de estudo enquanto expressão de uma entidade de natureza orgânica (a raça) e o mito da ordem corporativa que organiza o corpo da nação. Nos dois casos, estamos face a uma totalidade que forja uma ideia de essencialidade portuguesa, cuja definição e verdade é um modo de legitimar um discurso sobre o passado de Portugal e um projeto político para o seu Futuro. Nesta dinâmica, o mito palingenético e as leis da hereditariedade são ordens que servem para aferir o desvio relativamente à essência portuguesa, isto é, permitem revisitar o processo histórico para determinar os ciclos em que a essência se manifesta e os ciclos em que tal essência definha, permitindo ver e atuar, no presente, nas expressões de tal florescência ou degeneração. Nestes dois paralelos entre estes dois conceitos operacionais do programa de pesquisa de Mendes Corrêa e a mitologia do Homem Novo Estadonovista geram-se as condições para que, no discurso produzido a partir dos vestígios materiais pré-históricos, se estabeleça a reprodução dos restantes mitos. Neste entrelaçamento da prática científica com a prática política, produz-se a materialidade dos vestígios pré-históricos, permitindo que a pré -história se constitua um espaço de revelação do eterno no mortal, um tempo da hora do triunfo para a Justiça e para a Bondade e o lugar da comunidade daqueles que são pela Verdade e pelo Bem.

\section{AGRADECIMENTOS}

A Susana Soares Lopes, Ana Vale, Andreia Arezes e Andrew May pelas sugestões que me foram fazendo durante a realização deste trabalho. Aos dois revisores cuja leitura e sugestões críticas contribuíram para o enriquecimento do artigo. A investigação foi apoiada pela Fundação para a Ciência e a Tecnologia com a bolsa de pós-doutoramento SFRH/BPD/100203/2014 - financiada por fundos nacionais do MCTES, POCH e FCE.

\section{BIBLIOGRAFIA}

ABRunhosA, A. 2012. As escavações arqueológicas nos concheiros mesoliticos de Muge: contributo para o estudo da historiografia das investigações da década de 1930, Dissertação do 2. ${ }^{\mathrm{a}}$ Ciclo de Estudos em Arqueologia apresentada à Faculdade de Letras da Universidade do Porto. Edição Policopiada. 
ACCIAIUOLI, M. 1998. Exposições do Estado Novo: 19341940, Lisboa: Livros Horizonte.

BERLIN, I. 1999 [1988]. The Roots of Romanticism, London: Pimlico.

BRANDÃO, J.M. 2008/09. Uma intervenção na "Sala de Arqueologia Pré-histórica" do Museu Geológico (Lisboa), Revista da Faculdade de Letras. Ciências e Técnicas do Património I Série, Volume VII-VIII: 93-106.

CArdoso, J. L. 1999. O Professor Mendes Corrêa e a Arqueologia Portuguesa, Al-Madan II Série N. ${ }^{\circ} 8:$ 138-156.

CARdoso, J. L. \& Rolão, J. M. 1999/2000. Prospecções e escavações nos concheiros mesolíticos de Muge e de Magos (Salvaterra de Magos): contribuição para a história dos trabalhos arqueológicos efectuados, Estudos Arqueológicos de Oeiras: 83-240.

CARDoso, J. L. 2001/02. Correspondência anotada de Abel Viana e O. da Veiga Ferreira, Estudos Arqueológicos de Oeiras 10: 415-608.

CARDoso, J. L. 2002. História Breve das Investigações Préhistóricas em Portugal. In CARDOSO, J. L. (autor) Pré-história de Portugal, Lisboa: Editorial Verbo: 19-43.

CARdoso, J. L. 2008. O. da Veiga Ferreira (1917-1997): sua vida e obra científica. Homenagem a Octávio da Veiga Ferreira, Estudos Arqueológicos de Oeiras 16: $13-123$

CARdoso, J. L. 2010. O Professor Mendes Corrêa e a Arqueologia portuguesa, Anais da Academia Portuguesa da História, Série III, 2: 229-297.

CARdoso, J. L. 2010/11a. Francisco Jordá Cerdá (19142004) e a arqueologia portuguesa, Estudos Arqueológicos de Oeiras 18: 619-622.

CARdoso, J. L. 2010/11b. O Professor Mendes Corrêa (1888-1960) e as investigações sobre o Homo afer taganus dos concheiros mesolíticos de Muge, Estudos Arqueológicos de Oeiras 18: 631-656.

CARdoso, J. L. 2011. Mendes Corrêa e a arqueologia portuguesa: breve síntese. In MARTINS, A. C. (ed.) Mendes Corrêa (1888-1960): entre a ciência, a docência e a politica, Lisboa: ACD Editores: 75-84.

Certeau, M. de 1982 [1975]. A Escrita da História, Rio de Janeiro: Editora Forense-Universitária.

Coelho, R. G. no prelo. O Arqueólogo Cordial. A Junta Nacional da Educação e o enquadramento institucional da arqueologia portuguesa durante o Estado Novo (1936-1974).

CorrêA, A. A. M. 1919. Raça e Nacionalidade, Porto: Editores Renascença Portuguesa.

CorrêA, A. A. M. 1940 [1938]. Três séculos de labor arqueológico. In CORRÊA, A.A.M. (autor) $D a$ Raça e do Espirito, Porto: Imprensa Portuguesa: 169-190.

CorrêA, A. A. M. 1943. Raças do Império, Porto: Portucalense Editora.

CorrêA, A. A. M. 1944. Proémio. In CorrêA, A.A.M. (autor) Gérmen e Cultura, Porto: Imprensa Portuguesa/SPAE: V-VIII.

CorrêA, A. A. M. 1944 [1938]. Raizes de Portugal, Lisboa: Editorial Império/Revista Ocidente.
CORRÊA, A. A. M. 1944 [1940]. Da Pré-história à História Portuguesa. Discurso na sessão inaugural do I Congresso do Mundo Português. In CorrêA, A.A.M. (autor) Gérmen e Cultura, Porto: Imprensa Portuguesa/SPAE: 31-41.

CORRÊA, A. A. M.1954 [1951]. Rev. Padre Eugénio Jalhay, S.J. Elogio Proferido na sessão de homenagem de 18 de Janeiro de 1951 na Associação dos Arqueólogos Portugueses. In CORRÊA, A.A.M. (autor) Antropologia e História, Porto: Imprensa Portuguesa/ SPAE: $319-334$.

CunHA, L. 2001. A Nação nas Malhas da sua Identidade. $O$ Estado Novo e a construção da Identidade Nacional, Porto: Edições Afrontamento.

DÍAZ-ANDREU, M. 1997. Conflict and innovation: the development of archaeological traditions in Iberia. In DíAZ-AndReU, M. \& KeAY, S.(ed.) The Archaeology of Iberia. The Dynamics of Change, London: Routledge: 6-33.

DÍAZ-ANDREU, M. 2007. Internationalism in the invisible college: Political ideologies and friendships in archaeology, Journal of Social Archaeology, Vol. 7 (1): 29-48.

EvANS, C. 1995. Archaeology against the State: Roots of Internationalism. In. UCKO, P. (ed.), Theory in Archaeology: a World Perspective, London: Routledge: 312-326.

FERro, A. 2007 [1938]. 6. ${ }^{\text {a }}$ Entrevista. In FERRO, A. (autor) Entrevistas a Salazar, Lisboa: Parceria A.M. Pereira Livraria Editora: 117-148.

FABIÃO, C. 1996. Archaeology and Nationalism: the Portuguese Case. in DíAZ-ANDreu, M. \& ChANPION, T. (ed.) Nationalism and Archaeology in Europe, London: UCL Press Limited 169-178.

FABIÃO, C. 1999. Um século de Arqueologia em Portugal I, Al-Madan, II. ${ }^{a}$ Série, N.o 8: 104-126.

FABĨ̃o, C. 2011. Uma História da Arqueologia Portuguesa, Lisboa: CTT - Correios de Portugal.

Foucault, M. 1997 [1971]. A Ordem do Discurso, Lisboa: Relógio D'Água.

Gomes, S. 2006/07. As identidades nacionais nos regimes ditatoriais: o caso da romanità na Itália Fascista e o reaportuguesamento salazarista, Revista da Faculdade de Letras. Ciências e Técnicas do Património: I Série, Volume V-VI: 189-224.

GOMES, S. 2011a. Internationalism and professionalization in Portuguese archaeology at the close of Estado Novo, Journal of Iberian Archaeology, N. ${ }^{\circ}$ 14: 7-26.

Gomes, S. 2011b. O Passado, a Identidade e as Teias do Governo. Estudos sobre os entrelaçamentos das práticas de produção do conhecimento arqueológico e da construção da identidade nacional salazarista. Dissertação de Doutoramento em Arqueologia apresentada à Faculdade de Letras da Universidade do Porto. Edição policopiada.

GuIGNON, C. 2001. Being as appearing: retrieving the Greek experience of Phusis. In: POLT, R. and FrIED, G. (eds) A Companion to Heidegger's Introduction to Metaphysics, 34-56. New Haven, Conn.: Yale University Press.

Henare, A., Holdbraad, M., Wastell, S. (ed.) 2007. Thinking trough things, New York: Routledge. 
HoBsBawm, E. 1992 [1983]. Introduction: Inventing Traditions. In Hobsbawm, E. e Ranger, T. (ed.) The Invention of Tradition, Cambridge: Cambridge University Press: 1-14.

INGOLD, T. 2007. Materials against materiality, Archaeological Dialogues, 14(1): 1-16.

Jorge, V.O., Jorge, S.O. 1996. Arqueologia Portuguesa no Século XX: alguns tópicos para um balanço, Trabalhos de Antropologia e Etnologia, 36: 143-58.

KAESER, M.A. 2002. On the International Roots of Prehistory, Antiquity 76: 170-177.

LILIOS, K. 1995. Nationalism and Copper Age research in Portugal during the Salazar regime (1932-1974)", in KoHL, P.L. and FAWCETT, C. (ed.) Nationalism, politics, and the practice of Archaeology, Cambridge, Cambridge university Press: 57-69.

Martins, A. C. 2005. A Associação dos Arqueólogos Portugueses na Senda da Salvaguarda Patrimonial. Cem Anos de Transformação (1863-1963), Dissertação de Doutoramento em Letras (História da Arte) apresentada à Faculdade de Letras da Universidade de Lisboa, Departamento de História. Edição policopiada.

Martins, A. C. 2009. O Megalitismo no discurso arqueológico português. Entre o Liberalismo e o Estado Novo: uma primeira e sumária mirada, Estudos Arqueológicos de Oeiras, 17: 607-616.

MARTINS, A. C. 2010. Iberian Crossroads: Archaeology and Dictatorships, Bulletin of the History of Archaeology 20(2): 21-31.

MARTins, A. C. 2011a. Crossing roads. The (inter) nationalization of Portuguese archaeology (The first half of the $20^{\text {th }}$ century), Journal of Iberian Archaeology, N. ${ }^{\circ} 14:$ 69-87.

Martins, A. C. 2011b. António Jorge Dias (1907-1973) e a Arqueologia em Portugal, O Arqueólogo Português Série V, 1: 329-357.

Martins, A. C. 2011c (editor). Mendes Corrêa (18881960): entre a ciência, a docência e a política, Lisboa: ACD Editores.

MARTins, A. C. 2011d. Mendes Corrêa (1888-1960) e a arqueologia coeva: (en)trechos. In MARTINS, A. C. (ed.) Mendes Corrêa (1888-1960): entre a ciência a docência e a política, Lisboa: ACD Editores: $37-$ 74

MARTins, A. C. 2012. Em busca do tempo perdido: a proteção arqueológica em Portugal e em Espanha (1. ${ }^{\mathrm{a}}$ metade do século XX), O Arqueólogo Português Série V, 2: 189-239.

MARtins A. C. 2012/13. A intermitência do Ser e do Agir. A Associação dos Arqueólogos Portugueses no Estado Novo (1933-1963), Arqueologia \& História, Vol. 64-65: 81-92.

MARtins, A. C. 2013. Manuel Heleno (1894-1970) e a arqueologia portuguesa no Estado Novo (um primeiro ensaio), Estudos Arqueológicos de Oeiras 20: 771-782.

Martins, A. C. 2015. O 1. ${ }^{\circ}$ Congresso Nacional de Arqueologia (1958): entre a internacionalização da ciência e o internacionalismo científico. In SALgueIro, A. et al (ed) Internacionalização da Ciência. Internacionalismo Científico, Casal de Cambra: Caleidoscópio: 193-206.
Martins, M. L. 1998. O Olho de Deus no Discurso Salazarista, Porto: Afrontamento.

Matos, P. F. 2012. Mendes Correia e a Escola de Antropologia do Porto: Contribuição para o estudo das relações entre antropologia, nacionalismo e colonialismo, Dissertação de Doutoramento em Ciências Sociais, especialidade de Antropologia Social e Cultural apresentada ao ICS-UL. Edição policopiada.

MELO, D. 2001. Salazarismo e Cultura popular (19331958), Lisboa: Imprensa de Ciências Sociais

Miller, D. (ed.) 2005. Materialities, Durham/London: Duke University Press.

Murray, T., Evans, C. 2008. Histories of Archaeology. A reader in the History of Archaeology, Oxford: Oxford University Press.

Neto, M.J.B. 2001. Memória, Propaganda e Poder. O Restauro dos Monumentos Nacionais (1929-1960), Porto: FAUP publicações.

Ó, J.R. 1999. Os anos de Ferro. O dispositivo cultural durante a «Política do Espírito» 1933-1949, Lisboa: Editorial Estampa.

PoLT, R. 2001. The question of nothing. In: PoLT, R. and FrIED, G. (eds) A Companion to Heidegger's Introduction to Metaphysics, 57-82. New Haven, Conn.: Yale University Press.

Pimenta, J. R. 1999. Arqueologia. In BARreto, A. e MónICA, M.F. (ed). Dicionário de História de Portugal. Volume de atcualização (1926-1974), Porto: Livraria Editora Figueirinhas: 115-118.

Pimenta, J. R. 2007. Geo-Historiografia da Cultura Castreja. 3 Ensaios, Porto: Figueirinhas: 49-84.

Pimentel, I. F. 2007. Mocidade Portuguesa Feminina Educada para ser boa esposa, boa mãe, católica e obediente, Lisboa: Esfera dos Livros.

RAPOSO, L. 1999. Arqueologia e Museus em Portugal desde finais do século XIX, Al-Madan II Série N.o 8: 169-176.

RAPOSO, L. 2007/08. Museu Nacional de Arqueologia, Instituição Centenária da Cultura Portuguesa, $A N N U A$ $L I A$, Lisboa/São Paulo: Editorial Verbo: 118-139.

RAPOSO, L. 2010. 1926 a 1936: a instalação da «ordem nova» e a arqueologia portuguesa. In CusTóDIO, J. 100 Anos de Património - Memória de Identidade, Lisboa: IGESPAR: 201-204.

RosasA, F. 2001. O Salazarismo e o Homem Novo: o Estado Novo e a questão do Totalitarismo, Análise Social, Vol. XXXV (157):1031-1054.

Salazar, A. O. (1936). As Grandes Certezas da Revolução Nacional. In SAlazAR, A. O. (autor) Discursos e Notas Políticas II (1935-1937), 2a Edição, Coimbra: Coimbra Editora Lda.: 125-141.

SALAZAR, A. O. (1940). Salazar, 800 anos de Independência. In SAlazAR, A. O. (autor) Discursos e Notas Politicas III (1938-1943), 2a Edição, Coimbra: Coimbra Editora Lda.: 253-259.

Thomas, J. 2004. Archaeology and Modernity, London: Routledge.

VIEIRA, J. 2010. Fotobiografias do Século XX: António de Oliveira Salazar, Lisboa: Círculo de Leitores.

Young, J. 2002. Heidegger's Later Philosophy. Cambridge: Cambridge University Press. 